\title{
ЗА ЛОГИЧКИОТ ХИЛОМОРФИЗАМ И ЗА ОДНОСОТ НА ФОРМАЛНАТА И НЕФОРМАЛНАТА ЛОГИКА
}

\section{Кратка содржина}

Во овој труд се третираат два главни теориски проблема. Најнапред, во него се прави осврт и критичка анализа на доминантните сфаќњ в во поглед на т.н. логички хиломорфизам. Под овој поим се подразбира гледиштето дека онтолошкото разликување на формата и на материјата, кое потекнува уште од Аристотеловите филозофски списи, може легитимно да се примени и врз таков вид ентитети какви што се логичките заклучоци, со чел да се покаже дека специфично логичкиот елемент ито тие го содржат се состои во нивниот формален, а не во нивниот материјален аспект. Понатаму, во светлината на современата дискусија околу логичкиот хиломорфизам и неговите теориски консеквенции, се анализира конщептот на т.н. неформална логика, образуван во противстав на формалната логика. Оваа анализа има за чел да ја поткрепи главната теза на трудот, која се состои во тврдењето дека со чел да се избегнат многубројните теориски конфузии околу статусот и основните преокупации на логиката како дисчиплина, неопходно е да се изведе своевидна реконцептуализачија на нејзините основни определби, инспирирана од едно потироко сфаќање за рачионалноста, кое ги вклучува не само нејзините аналитички, туку и нејзините дијалектички облици.

Клучни зборови: ЛОГИЧКИ ХИЛОМОРФИЗАМ, ДИСТИНКЦИЈА ФОРМА-МАТЕРИЈА, ФОРМАЛНА ЛОГИКА, НЕФОРМАЛНА ЛОГИКА, АРГУМЕНТАЦИЈА

Увод

Според доминантното и широко прифатено гледиште за концептот на логичката валидност во рамките на современата логика, она врз што се темели логичката валидност на заклучоците е нивната форма, а не нивната „материја“, односно содржина. Сепак, обидот за прецизно и недвосмислено определување на поимот на формата во различните логички контексти се судира со голем број тешкотии. Во современите истражувања од областа на логиката се водат интензивни дискусии поврзани со разликувањето на повеќе значења што се поврзуваат со овој поим, а тоа, од своја страна, има сериозни последици за сфаќањето на формалната логика како дисциплина и на нејзините основни преокупации.

Имајќи ја предвид генералната рамка на споменатите теориски дискусии, во овој труд акцентот најнапред ќе биде ставен врз разработката на теориската 
контроверзија поврзана со т.н. „логички хиломорфизам“. Со овој современ термин, инспириран од античките, а особено од Аристотеловите филозофско-логички концепции, се означува сфаќањето дека онтолошкото разликување на формата и на материјата може легитимно да се примени и врз таков вид ентитети какви што се логичките заклучоци, со цел да се покаже дека специфично логичкиот елемент што тие го содржат се состои во нивниот формален, а не во нивниот материјален аспект. Понатаму, сознанијата артикулирани во контекст на расправата околу значењето, консеквенциите и перспективите на логичкиот хиломорфизам ќе бидат применети во обидот поблиску да се определи односот меѓу формалната и неформалната логика како теориски подрачја, чија дефиниција и демаркација, исто така, е еден од горливите проблеми во современата филозофија на логиката. Целта на промислувањето на односот помеѓу овие две подрачја е да се преиспитаат некои од имплицитните теориски претпоставки за смислата и задачите на логиката како дисциплина, во светлината на една поширока концепција за расудувањето која не се потпира единствено врз аналитичкиот, туку го вклучува и дијалектичкиот образец на рационалноста.

\section{1. Логичкиот хиломорфизам и неговата генеза}

Како општа филозофска концепција, хиломорфизмот го означува Аристотеловото сфаќање дека постојните нешта се сочинети од материја (hyle) и од форма (morphe). Ова сфаќање, од своја страна, се развива во рамки на неговата општа теорија за причиноста и објаснувањето, позната како учењето за „четирите причини“: материјалната, формалната, дејствената и целната причина. (Met. V) Според ова учење, кога сакаме да објасниме во што се состои знаењето за определен објект, на пример, за една бронзена статуа што го прикажува богот Хермес, целосното објаснување треба да ги опфати следниве четири фактори (причини, aitiai): материјата од која е составена статуата (материјалната причина - во овој случај бронзата), нејзината форма или структура (формалната причина - ликот на Хермес), дејствителот одговорен за тоа што таа материја ја манифестира соодветната форма или структура (дејствената причина - скулпторот што ја обликува статуата) и целта поради која таа материја ја добила својата форма или структура (целна причина - оддавање почит на богот Хермес). Аристотеловиот хиломорфизам игра особено голема улога во неговото објаснување на функционирањето на живите организми, при што кај нив душата е претставена како форма на телото, а телото како материја на душата; сепак, како што покажа споменатиот пример со статуата, релацијата на материјата и на формата важи и за други типови ентитети, особено оние што спаѓаат во категоријата „први супстанции“ - индивидуалните, поединечни нешта, без оглед дали се создадени на природен или на вештачки начин.

Со оглед на општоста на тезата на хиломорфизмот, од една страна, и на фактот дека Аристотел е основач на формалната логика како дисциплина, оправдано би било да се постави прашањето за тоа дали во неговата теорија има место и за т.н логички хиломорфизам, односно за тезата дека разликувањето на материјата и на формата е клучно за објаснувањето на структурата и функцијата и на апст- 
рактните ентитети какви што се логичките заклучоци и дека токму во нивниот формален аспект лежи суштината на логичкото. И покрај фактот што на прв поглед се чини дека ова гледиште адекватно ја изразува Аристотеловата позиција, влијателни современи истражувачи од областа на логиката и нејзината историја ја застапуваат тезата дека потеклото на логичкиот хиломорфизам е од подоцнежен датум и дека во изворните Аристотелови списи не може да се најде основа за нему да му се припише ваквото гледиште. Како што подвлекува МекФарлејн,

Изненадувачки, таткото и на формалната логика и на хиломорфизмот не е и таткото на логичкиот хиломорфизам. Аристотел ја применува својата дистинкција меѓу формата и материјата врз логиката само еднаш: во Физика, тој тврди дека премисите на еден заклучок се однесуваат кон неговата конклузија како што материјата се однесува кон формата (II. 3. 195а16-21). [] Смислата на ова тврдење е во тоа дека исто како што за да се изгради куќа се потребни камења, и премисите се потребни за да се изведе конклузија (cf. II. 7.198b7-8). Во ниедно од Аристотеловите дела нема трага од дистинкцијата помеѓу „формалната“ и „материјалната“ консеквенција. Всушност, концептите на форма и материја се целосно отсутни од Органонот. (MacFarlane, 2000, p. 255)

Во историска смисла, првата експлицитна употреба на концептите на материјата и формата со цел да се карактеризира логиката и нејзините темелни преокупации се среќава во коментарите што ги дава Александар Афродизиски, околу 200 г. н.е., за Аристотеловите логички дела. Сепак, историските извори укажуваат дека примената на хиломорфистичката терминологија врз логиката најверојатно не е инвенција на самиот Александар, туку на некој од претходните перипатетички мислители чиј идентитет е непознат, како што остануваат непознати и конкретните разлози поради кои во определен историски миг употребата на хиломорфистичката терминологија била проширена и врз логиката. (MacFarlane, 200, pp. 255256) Логичкиот хиломорфизам опстојува во различни варијанти во античката и во средновековната логика, додека кај нововековните мислители негова експлицитна (ре)афирмација се среќава кај Кант. Според МекФарлејн, хиломорфистичката перспектива во поглед на логиката кај Кант е една од теориските импликации на неговиот трансцендентален идеализам. Во оваа интерпретација, формалниот карактер на логиката произлегува токму од нејзината општост, затоа што универзалните и нужни правила на мислењето не можат да ја засегаат неговата материја, туку единствено неговата форма. (MacFarlane, 2000, p. 121).

Како резултат на голем број историски и теориски фактори, хиломорфистичката позиција е, на повеќе или помалку експлицитен начин, присутна и во современата логика. Нејзината доминантна верзија Катарина Дутилх Новаес ја опишува како доктрина која може да се разложи на неколку фундаментални тези. Најнапред, оваа варијанта на хиломорфизмот се темели врз гледиштето дека во секој заклучок постои нешто што соодветствува на неговата форма и нешто што соодветствува на неговата материја. Притоа, формата на заклучокот е определена од едно (вистинско) подмножество од множеството елементи на јазикот на кој тој е изразен, организирани во соодветен распоред, додека материјата на аргументот ја сочинуваат преостанатите елементи, образувајќи подмножество комплементарно 
на подмножеството елементи што ја сочинуваат неговата форма. Така сфатената форма на заклучокот е она што ја определува неговата валидност (правилност) и може да се претстави преку соодветна шема. Следствено, имајќи предвид дека логиката претставува систематско проучување на валидноста на заклучоците, таа се интересира првенствено за нивната форма. Тоа систематско проучување ја користи техниката на супституција, која се состои во тоа што на местото на елементите на заклучокот што се однесуваат на неговата материја се ставаат различни термини со што се генерираат повеќ инстанции на една иста форма на заклучокот, додека елементите што се однесуваат на неговата форма остануваат непроменети. Така, термините што остануваат непроменети се оние што се однесуваат на формата на заклучокот и тие се, всушност, неговите логички термини (познати и како логички константи, токму поради тоа што остануваат фиксни); од друга страна, термините што се подложни на супституција, односно термините што се варираат и, според тоа, припаѓаат на неговата материја, се вонлогичките термини на дадениот заклучок. Според тоа, демаркацијата на логиката како дисциплина се одвива преку демаркација на класата на логичките константи, бидејќ логиката се занимава со проучувањето на формите на заклучоците, а со самото тоа логичките константи претставуваат примарен предмет на нејзиниот теориски интерес. (Dutilh Novaes, 2012, pp. 395-396). ${ }^{1}$

И покрај тоа што овој корпус од тези, барем во најголем дел, звучи сосем прифатливо за стандардното разбирање на современиот логичар, според укажувањето на Дутилх Новаес, неговата попродлабочена анализа ќе покаже дека споменатите тези почиваат врз извесни имплицитни (метафизички) претпоставки чие оставање во нерасветлена форма може да создаде непосакувани концептуални конфузии. Најнапред, современата верзија на хиломорфизмот претставува варијанта на т.н. мереолошки хиломорфизам, според кој материјата и формата претставуваат засебни делови на целината што ја сочинуваат. Сепак, според аргументацијата на Дутилх Новаес, мереолошкото сфаќње на хиломорфизмот не соодветствува на изворната Аристотелова концепција, според која формата не е, во стриктна смисла, дел на целината, туку таа попрво претставува принцип на единството што ги артикулира различните делови на целината, кои ја сочинуваат нејзината материја. Понатаму, современата варијанта на хиломорфизмот го сугерира гледиштето дека поделбата на форма и на материја на определен заклучок е уникатна, односно дека постои една и само една вистинска форма на заклучокот врз која се темели неговата валидност. Но наспроти ова сфаќање може да се наведе аргументот дека различни логички гранки (на пример, логиката на исказите и логиката на предикатите) нудат различни начини на кои може да се претстави логичката форма на еден ист конкретен заклучок. Најпосле, современата варијанта на хиломорфизмот го претставува разликувањето на формата и на материјата на еден заклучок како принципиелно и строго, како да станува збор за реална онтичка дистинкција присутна во него, бидејќи само врз основа на оваа претпоставка има смисла

\footnotetext{
${ }^{1}$ Ваквото сфаќањ на формалноста Дутилх Новаес го карактеризира како „шематско сфаќање на формалноста“, и за него ќе стане збор понатаму во текстот.
} 
тврдењето дека валидноста на аргументите се темели врз нивната форма и дека од демаркацијата на логичките константи може да произлезе соодветна демаркација на логиката како дисциплина. (Dutilh Novaes, 2012, pp. 396-397). Но повторно, и оваа поставка може суштински да се проблематизира, затоа што критериумот за разграничување на логичките од вонлогичките изрази што се употребуваат во заклучувањето тешко може да се дефинира на универзален начин, независно од даден логички систем и од целите за кои тој се користи. Ова е сосем видливо во начинот на кој, во современата логика, се конструираат системите на т.н. некласични логики: така, доколку целта е да се проучува логичкото функционирање на модалните поими, модалните зборови (можно, нужно) се третираат како логички константи; доколку целта е во тоа да се истражуваат епистемичките поими (знае, верува) или деонтичките поими (дозволено, забрането итн.) тогаш епистемичките или деонтичките термини добиваат статус на логички константи, итн.

Имајќи ги предвид споменатите аспекти на современата верзија на хиломорфизмот, што ја нарекува LHAWKI („logical hylomorphism as we know it”) Дутилх Новаес го сугерира гледиштето дека оваа верзија е само еден од возможните исходи - и тоа, во основа, дубиозен исход - од комбинирањето на хиломорфизмот и логиката. Таа смета дека поадекватен приод кон проблемите поврзани со логиката што се третираат во рамките на постојната варијанта на хиломорфизмот би се реализирал со прифаќње на некоја од следните три опции (со кои, секако, не се исцрпува бројот на можните алтернативи): 1) радикално отфрлање на објаснувачката моќ на хиломорфичката рамка кога станува збор за логиката; 2) примена на поимите на материјата и на формата врз логичките објекти единствено во аналошка и метафорична смисла, без дополнителни теориски обврзувања или проекции и 3) фокусирање врз поинакво сфаќае за хиломорфизмот како појдовна точка за развивање на еден специфично логички хиломорфизам (Dutilh Novaes, 2012, p. 409). Сепак, без оглед на тоа дали би се прифатиле овие сугестии или би се развивале аргументи во одбрана на постојната, современа верзија на хиломорфизмот, останува фактот дека проблемите што ги инспирира дискурсот за материјата и за формата на логички план не би можеле адекватно да се третираат доколку најнапред не се разјасни повеќезначноста на самите концепти на материјата и формата употребени во логичка смисла. Со оглед на неспорниот примат што целата традиција на логиката го дава на поимот на формата, за што сведочи и синтагмата „формална логика“" како едно од најчесто употребуваните имиња за оваа дисциплина сфатена во современа смисла, во следниот дел од текстот ќ биде направен осврт врз различните значења во кои поимот на формата се употребува во логички контекст, особено во поглед на неговото значење при дефинирањето на основните преокупации на логиката како дисциплина.

\section{2. Различните сфаќања за формата и формалноста во современата логика}

Еден од највлијателните обиди да се расчистат теориските недоумици што произлегуваат од недоволното прецизирање на значењето на поимот на формата во современите логички дискусии потекнува од почетокот на осумдесеттите 
години на дваесеттиот век. Овој обид е поврзан со имињата на Елзе Барт и Ерик Крабе, истакнати логичари кои во своето фундаментално дело From Axiom to Dialogue разликуваат три основни значења на овој поим:

1) Форма 1 - смисла во која овој термин означува нешто слично на Платоновата идеја како фундаментална метафизичка единица;

2) Форма 2 - смисла во која се има предвид логичката структура на речениците, онака како што нив ги сфаќа современата логика; синтаксата на јазикот на кој припаѓаат овие реченици е мошне прецизно формулирана или формализирана, а валидноста на заклучоците изразени во него е дефинирана преку логичката форма на речениците што го сочинуваат дадениот заклучок;

3) Форма 3 - во оваа смисла, поимот на формата се однесува на процедурите кои се регулирани на определен начин, односно кои се одвиваат во согласност со определено множество од правила. (Barth \& Krabbe 1982, p.14 ff.)

Притоа, второто значење на поимот на формата се смета за најрелевантно за определувањето на современото сфаќање на логиката, а како што ќе се покаже во натамошниот дел од текстот, и за разграничувањето на полињата на формалната и т.н. неформална логика.

Сепак, оваа идеја на Барт и Крабе за конститутивната улога на дефиницијата на формата во определувањето на логиката како дисциплина и на нејзините основни преокупации добива нов импулс и понатамошно продлабочување во логичките истражувања што го обележуваат почетокот на дваесет и првиот век. Така, во својата докторска дисертација од 2000 година со наслов What does it mean to say that logic is formal? Џон МекФарлејн истакнува дека според вообичаеното сфаќње на современите логичари, идејата дека логиката по својата суштина е формална се третира како саморазбирлива, при што како непроблематични се посочуваат следниве значења на придавката „формална“:

- логиката може да се третира на чисто синтаксички начин, без упатување на значењата на изразите (синтаксичка формалност);

- логичките закони се шематски, односно тие содржат „празни места“ на кои можат да се стават кои било „материјални изрази од соодветните категории“ (шематска формалност);

- логичките својства на речениците зависат единствено од нивните граматички форми или структури, односно од поредокот и распоредот на нивните граматички честички и граматичките категории на нивните „категорематички“" термини (граматичка формалност) (MacFarlane, 2000, ch.2)

Но, според МекФарлејн, овие вообичаени и непроблематични значења на формалноста не можат да придонесат за извршувањето на демаркациската задача - задачата на разграничувањето на она што е суштински логичко од она што не е такво. Затоа, тој споменатите три значења - синтаксичката, шематската и граматичката формалност - ги третира како „мамки“ (decoys) кои го одвраќаат вниманието од вистинската цел: критичкото испитување на хиломорфизмот и неговото ба- 
зично тврдење дека логиката е суштински формална, односно дека може да биде разграничена од другите подрачја токму врз основа на нејзината формалност. За таа цел, тој истакнува три други значења во кои логиката се нарекува формална значења што, иако не се еквивалентни, честопати се среќаваат заедно:

1) Значење според кое логиката се смета за формална врз основа на тоа што ги обезбедува конститутивните норми на мислењето како такво; во оваа смисла, формалните закони се законите кон кои мора да се придржува секој вид концептуална активност - тврдење, заклучување, донесување судови итн.;

2) Значење во кое формалноста на логиката се состои во нејзината индиферентност кон поединечните идентитети на објектите; поимите и законите што се формални во оваа смисла на секој поединечен објект - живо суштество, материјален објект, апстрактен ентитет - му даваат идентичен третман. Во математичка смисла, овој поим на формалноста е претставен како непроменливост (invariance) при сите пермутации во доменот на објектите;

3) Значење во кое логиката се третира како формална затоа што таа целосно се апстрахира од семантичката содржина на концептите, третирајќи ја мислата во целосна независност од нејзиниот однос во светот, и, следствено, е ослободена од какви и да било супстанцијални претпоставки. (MacFarlane, 2000, p. 51)

Во својата опстојна историско-логичка анализа МекФарлејн се обидува да покаже дека овие три значења се обединети во Кантовата (Kant) трансцендентална филозофија, но дека во други контексти - на пример, кај Фреге (Frege) - тие функционираат независно едно од друго. Свртувањето на вниманието кон историјата на логиката, според овој автор, може да ни помогне појасно да ги согледаме изворите на нашите диспаратни интуиции околу природата и суштината на логичкото, и да ги класификуваме овие интуиции како суштински или како акцидентални, со цел современата дебата околу демаркацијата на логиката како дисциплина да се постави на поцврсти теориски темели.

Сепак, во современите логички истражувања може да се сретне и гледиштето дека прашањето за различните значења во кои логиката се нарекува формална не треба се врзува исклучиво за потрагата по демаркациски критериум за суштината на логичкото, туку дека треба да се разгледа како прашање од самостоен теориски интерес, без притисок на „надворешна агенда“. Ваквото гледиште експлицитно го застапува Катарина Дутилх Новаес. Таа, со уважување на резултатите на МекФарлејн, но и со одредени критички забелешки во однос на неговите поделби, настојува да понуди една поисцрпна систематизатија на различните логички релевантни значења на поимот на формата. Таксономијата што таа ја предлага треба да придонесе кон зголемувањето на степенот на концептуалната јасност во современите дебати од областа на филозофијата на логиката и да послужи како теориско орудие во дискусијата за различни корпуси од нејзините фундаментални 
прашања. Така, Дутилх Новаес (2011) разликува осум главни варијации на поимот на формалното, распоредени во две групи.

Првата група ги опфаќа сфаќањата засновани врз формите (formal as pertaining to forms), а втората - сфаќањата засновани врз правилата (formal as pertaining to rules). За првата група е карактеристично тоа што сите значења што таа ги опфаќа можат да се сметаат за специфични интерпретации на слоганот „формално е она што се апстрахира од материјата“. Следствено, како што беше елаборирано во претходниот оддел посветен на логичкиот хиломорфизам, спротивниот поим на поимот на формалното е поимот на материјалното, и во зависност од тоа како ќe се сфати самиот поим на материјата, интерпретацијата на овој општ слоган ќе генерира различни поими на формалното. Имено, во ова сфаќање, формата е она што останува откако ќе се апстрахираме од материјата на заклучувањето. Така, 1) доколку материјата на еден аргумент соодветствува на специфична поткласа на неговите термини, имено, оние што имаат значење сами по себе, т.е. реферираат на нештата (во средновековната логика познати под името „категорематички термини“"), тогаш го добиваме шематскиот поим на формалното. 2) Доколку материјата на заклучокот ја претставуваат специфичните нешта на кои се реферира во заклучокот, тогаш го имаме поимот на формалното како индиферентност кон поединечните нешта. 3) Доколку под материја на аргументот се подразбира специфичната област на која тој се однесува, тогаш станува збор за формалното како независно од конкретната област на расудувањето (topic-neutral). 4) Ако материјата на заклучувањето е претставена со неговата интенционална содржина, односно со неговата релација со објектите во светот, тогаш поимот на формалното се состои во апстракиијата од содржината (abstraction from content). 5) Најпосле, ако како материја на аргументот се смета неговата содржина во смисла на значењето што го имаат неговите термини, тогаш го имаме поимот на формалното како де-семантификаиија, односно радикално лишување на формалните симболи од секакво значење, при што под „форма“ тогаш се подразбира самиот облик на симболите.

Како што подвлекува Дутилх Новаес, меѓу сфаќањата наведени во оваа група шематската интерпретација на формалното е историски најстара, и произлегува од применувањето на аристотеловската дистикција на материјата и формата врз силогизмите, изведено од страна на античките коментатори (за што стана збор во одделот посветен на хиломорфизмот). Другите варијации потекнуваат од него, и се во поголема или помала мера влијателни во различни периоди и контексти, вклучувајќи го и современиот период. Како главна карастеристика на оваа група сфаќања на формалното се истакнува фактот што тука концептот на формата се поврзува со нешто што е, што постои како определена (апстрактна) структура.

За разлика од неа, втората група сфаќања за формалното, базирана врз концептот на правилата, суштествено е поврзана со дејствувањата и акциите и во таа смисла има поизразено нормативно значење. Оваа група сфаќања за формалното, исто така опфаќа повеќе варијанти: 1) варијанта во која формалното се сфаќa како она што е подложно на пресметување; 2) варијанта во која формалното се 
однесува на регулативните правила; 3) варијанта во која формалното се однесува на т.н. конститутивни правила, сфатени во Серлова (Searle) смисла.

Во својот критички осврт кон таксономијата на Дутилх Новаес, Елена Драгалина - Чернаја забележува дека определбата на формалното како „она што се однесува на формите“ се чини тавтолошка, додека неговата определба како „она што се однесува на правилата“ се чини премногу тесна. Затоа, таа сугерира поинаква дихотомна дистинкција меѓу моделите на формалноста: дистинкција помеѓу статичните, т.н. супстанцијални модели, и помеѓу динамичките модели кои ги опфаќаат не само правилата, туку и целите на дејствувањето. (Dragalina-Chernaya, 2015). Сепак, не негирајќи ја основаноста на оваа и на слични критички забелешки што можат да ѝ се упатат на класификацијата на Дутилх Новаес, важно е да се истакне дека таа укажува на уште една плодотворна концептуална дистинкција што е од особено значење за главната цел на овај труд. Имено, Дутилх Новаес сугерира дека дистинкцијата на формите и правилата како база за различните сфаќања на формалноста овозможува да се воспостави и соодветната дистинкција на поимите што ним им се спротивни: така, како што беше и претходно споменато, во сфаќањето на формалното како она што се однесува на формите, она што не е формално вообичаено се нарекува материјално, додека во сфаќањето на формалното како она што се однесува на правилата, она што не е формално вообичаено се нарекува неформално. Без оглед на тоа дали е сосем прифатлив конкретниот принцип на разграничување, важно е дека овие дистинкции го отвораат патот кон следното прашање што е од централен интерес за овој труд - концептуалната основаност на синтагмата „неформална логика“, која се користи за означување на едно специфично подрачје на современите истражувања чиј однос со т.н. формална логика е предмет на многубројни теориски контоверзии.

\section{3. За концептот на „неформалната логика“: предности и недостатоци}

Во историска смисла, под синтагмата „неформална логика“ се подразбира интелектуално движење иницирано во доцните седумдесетти години на дваесеттиот век во САД и Канада, во чии рамки група филозофи, кои себеси се нарекуваат „неформални логичари“, иницираат своевидно нормативно проучување на аргументацијата од гледна точка различна од онаа карактеристична за приврзаниците на формалната логика. Во почетната фаза од развојот на оваа теориска ориентација, терминот „неформална логика“ првенствено се користи како средство за потенцирање на различноста на овој приод кон анализата и евалуацијата на заклучоците и аргументите во споредба со приодот кој го користи формалната логика. Така, според Џонсон и Блер, „неформалната логика ја означува онаа гранка на логиката чија задача е да развие не-формални 2 стандарди, критериуми, процедури за анализа, интерпретација, евалуација, критика и конструкција на аргументацијата во секојдневниот јазик“. (Johnson \& Blair, 2000, p. 94). Употребата на терминот неформални 2 упатува на претходното споменатата дистинкција на различните значења на поимот на формата предложена од Барт и Крабе. Според оваа дистинкција, форма $_{2}$ го сумира сфаќањето карактеристично за современата формална логика 
базирано врз употребата на вештачки симболички јазици и врз идејата дека валидноста на расудувањето зависи од логичката структура на речениците вклучени во него. Сепак, Џонсон и Блер истакнуваат дека неформалноста на неформалната логика не значи дека таа не користи никакви стандарди, критериуми или процедури за евалуација на заклучоците и расудувањето, туку само дека таа го отфрла гледиштето дека логичката форма, сфатена во смисла на Расел (Russell) и останатите логицисти, го има клучот за разбирање на структурата на сите аргументи, како и гледиштето дека валидноста е соодветен стандард чие задоволување се очекува од сите видови аргументи. Според овие автори, теориската дејност развиена во рамките на неформалната логика може да се согледа како обид за реконцептуализација на феноменот на аргументацијата и за негово ослободување од врзаноста за таканаречениот геометриски или математички модел. Тоа значи, помеѓу другото, ослободување од дедуктивизмот, односно од идејата дека сите заклучоци се или дедуктивни или логички „дефектни“, како и од идејата дека сите заклучоци мора да претставуваат докази во стриктната логичка смисла на овој збор. (Johnson and Blair, 2000, pp. 101-102).

Сепак, и покрај предноста што ја има синтагмата „неформална логика“ во смисла на тоа што таа јасно ја изразува воочената потреба да се ограничи теорискиот хегемонизам на формалната логика во проучувањето и евалуацијата на облиците на расудувањето, нејзиниот најпроблематичен аспект се состои во негативниот начин на кој таа се идентификува - преку она што таа не е, наместо преку она што таа $e$. Проблемот дополнително се компликува со големата разновидност на значењата на поимот на формалното разработена во претходниот оддел од текстот, во таа смисла што доколку неформалната логика се дефинира како опозит на формалната логика, следува дека би требало да има исто толку значења и варијанти на неформалната логика колку што има различни значења и варијанти на формалната логика. Но, како што видовме и претходно, меѓу значењата на поимот на формалното постои сложена и компликувана мрежа на сличности и разлики, која соодветно се рефлектира и во обидот за негативно определување на приодот на неформалната логика. Од тоа, од една страна, произлегува своевидна неконзистентност, а од друга страна, редундантност на теориските алатки и критериуми што ги развива неформалната логика, така што нејзината хетерогеност го попречува развојот на конзистентна и сестрано обмислена платформа како теориска алтернатива на формалната логика. Но, сепак, во последните децении на дваесеттиот век, токму од оваа хетерогеност на приодот на неформалната логика се развиваат низа значајни правци кои отвораат нови перспективи во проучувањето на феномените на расудувањето, какви што се, на пример, движењето на т.н. критичко мислење, дијалектичкиот и прагма-дијалектичкиот приод кон аргументацијата, интегрирањето на увидите од теоријата на вештачката интелигенција и компјутациските модели во проучувањето на аргументацијата, особено онаа изразена со средствата на природниот јазик, итн. Во рамките на овие приоди, се развиваат значајни прашања поврзани со самата природа на расудувањето, заклучувањето и аргументацијата, како што се прашањата за дефинициите на поимите „расудување“, „заклучување“ и „аргументација“ и сродните на нив базични логички кон- 
цепти, за можните класификации на типовите заклучоци и аргументи, за идентификацијата и интерпретацијата на аргументите, за разликата меѓу нивните имплицитни и експлицитни елементи, за различните видови аргументациски структури, за критериумите и стандардите на евалуација на заклучоците, за логичките грешки и начините на нивно идентификување и справување со нив, итн. (Eemeren et al., 2014 , ch. 7). Имајќи го предвид значењето, дострелот и импликациите од решавањето на овие прашања, станува јасно дека самото подрачје на неформалната логика е од огромно теориско значење, и дека почетниот ривалитет со истражувањата од областа на формалната логика мора да се релативизира, бидејќ е очигледно дека меѓу областите на истражување на формалната и неформалната логика постои длабока, суштинска поврзаност.

\section{Заклучни согледби}

Во логичките истражувања од првите децении на дваесет и првиот век сѐ позачестени се гледиштата во кои се потенцира сознанието за комплементарноста на предметите и методите на формалната и оние на неформалната логика. Ова сознание се темели врз фактот дека логички релевантните феномени на расудувањето не ги вклучуваат само класичните дедуктивни структури што можат релативно едноставно да се проучуваат со помош на формализираните јазици, туку еден значително поширок круг на контекстуално вкоренети заклучоци, суштествено врзани за ресурсите на природниот јазик и за специфичноста на областите на кои се однесуваат. Во таа смисла, посочената комплементарност на формалната и на неформалната логика укажува на потребата од оформување на еден поширок концепт на логиката како дисциплина, сфатена како своевидна општа теорија на рационалноста, во која свој теориски третман ќе најдат, зборувајќ со аристотеловски термини, не само облиците на аналитичкото, туку и оние на дијалектичкото расудување.

Сепак, доколку ги земеме предвид елаборациите изнесени во првиот дел на текстот, посветен на логичкиот хиломорфизам и на неговите теориски аспекти, а особено на неговите скриени претпоставки и имплицитните концептуални конфузии што тој ги опфаќа, би можеле да ја сугерираме следната идеја: инсистирањето врз применувањето на дистинкцијата форма - материја врз феномените на расудувањето и фокусирањето врз формалниот аспект на логиката како демаркациски критериум за нејзината суштина, и покрај сите предности, генерира и низа суштински проблеми. Тие проблеми првенствено се однесуваат на определувањето на централните преокупации на логиката како дисциплина и несоодветна диференцијација на нејзините подрачја на формална и неформална логика. Дури и ако се прифати тезата за комплементарноста на овие подрачја, што претставува напредок во однос на почетната спротивставеност на овие две сфери, остануваат нерасчистени голем број прашања околу заемниот однос на нивните методи и теориски цели. Затоа, една од можностите што се отвораат, и што, на некој начин беа сугерирани во анализите на Катарина Дутилх Новаес за перспективите на логичкиот хиломорфизам, е оттргнувањето од милениумската доминација на хиломорфистичкиот дискурс во логиката и неговиот фокус врз формата (во поглед на која, ка- 
ко што беше покажано, постојат голем број различни и спротивставени интуиции) и развивање на поинаква концептуална рамка на организација на полето на логиката како дисциплина. Во конструирањето на една таква рамка како појдовна точка би можеле да се земат други дистинкции присутни во подалечната или во поновата историја на логиката, како што беше, на пример, споменатата Аристотелова дистинкција на аналитичките и дијалектичките расудувања, или поделбата на семиотиката (општата теорија за знаците), која се разгранува на синтакса (гранка што го проучува меѓусебниот однос на знаците), семантика (гранка што го проучува односот на знаците кон нивните значења), и прагматика (гранка што го проучува односот на знаците кон нивните корисници). Впрочем, во современите логички истражувања веќе можат да се сретнат такви обиди за реконцептуализација на односот на формалната и неформалната логика низ една од споменатите алтернативни теориски призми. Еден од таквите обиди е, на пример, сугестијата на Даглас Волтон дека формалната логика, проучувајќи ги формите на заклучоците и вистинитосните вредности всушност се занимава со синтаксичките и семантичките аспекти на расудувањето, додека неформалната логика, која ја проучува аргументацијата во дијалошки контекст, се занимава со неговите прагматички аспекти (Walton, 1990, pp. 418-419). Интересен е фактот што Волтон смета дека неформалната логика, сфатена во поширока смисла, всушност коинцидира со теоријата на аргументацијата. Поаѓајќи од оваа идеја, би можело да се застапува тезата дека три клучни подрачја на логичките истражувања се логичката синтакса (развиена во облик на теорија на доказот), логичката семантика (развиена во облик на теоријата на вистината) и логичката прагматика (развиена во облик на теоријата на аргументацијата). Како што покажуваат современите логички истражувања, сите овие подрачја можат да се третираат и на формален и на неформален начин, што му дава дополнителна тежина на ставот дека аспектот на формалноста во логиката поскоро треба да се третира како одлика на нејзиниот метод (поточно, на дел од нејзините методи), а не како суштествена одлика на самиот нејзин предмет како дисциплина. Така, преку релативизацијата на дистинкцијата формална-неформална логика и користењето на алтернативни теориски дистинкции се отвора простор за нови истражувања од областа на филозофијата и историјата на логиката, што бараат далеку поголем простор и посистематски приод отколку што тоа го овозможуваат границите и целите на овој труд, но кои, од друга страна, ја покажуваат отвореноста и интелектуалната живост на логиката како едена од фундаменталните филозофски дисциплини. 


\section{Литература}

Aristotle. (1933, 1989). Metaphysics. Translated by Hugh Tredennick. Cambridge, MA: Harvard University Press; London: William Heinemann Ltd.

Barth, E. M. \& Krabbe, E. C. (1982). From Axiom to Dialogue: A Philosophical Study of Logics and Argumentation. New York/Berlin: De Gruyter.

Dragalina-Chernaya, E. (2015) The Roots of Logical Hylomorphism. Basic Research Program - Working papers. Series: Humanities WR BRP 88/hum/2015. https:// www.hse.ru/data/2015/02/24/1090738182/88HUM2015.pdf

Dutilh Novaes, C. (2012). Reassessing Logical Hylomorphism and the Demarcation of Logical Constants. Synthese 185, 387-410.

Dutilh Novaes, C. (2011). The different Ways in which Logic is (said to be) Formal. History and Philosophy of Logic 32, 303-332.

Eemeren, F. H. v \& al. (2014). Handbook of Argumentation Theory. Dordrecht/Heidelberg/New York/London: Springer.

Johnson, R. H. (1999). The Relation between Formal and Informal Logic. Argumentation 13, 265-274.

Johnson, R. H. \& Blair, J. A. (2000). Informal Logic. An overview. Informal Logic, 20 (2), 93-107.

MacFarlane, J. (2000). What does it Mean to Say that Logic is Formal? Unpublished $\mathrm{PhD}$ dissertation, Pittsburgh University.

Walton, D. (1990). What is Reasoning? What is and argument? Journal of Philosophy 87, 399-419. 
Ana DIMISHKOVSKA

\section{ON LOGICAL HYLOMORPHISM AND THE RELATION BETWEEN FORMAL AND INFORMAL LOGIC}

\section{Summary}

This paper is focused on two main theoretical topics. First, it summarizes and critically analyzes the dominant contemporary interpretations of what is called "logical hylomorphism". This expression, coined by John MacFarlane, designates the conception according to which the ontological distinction of form and matter, rooted in Aristotle's philosophical writings, can be applied to arguments and inferences in order to show that the specifically logical element that they contain is related to their formal, and not to their material aspect. Second, in the light of the contemporary discussions on logical hylomprphism and its theoretical consequences, the author analyzes some of the dominant conceptions of informal logic as opposed to formal logic. The point of this analysis is to corroborate he main thesis of the paper: the idea that in order to avoid the current conceptual controversies concerning the status and the main preoccupations of logic as a discipline, it is necessary to reconceptualize some of its fundamental notions and theoretical distinctions, in the light of an enlarged conception of rationality, which includes not only the anaytical, but also the dialectical aspects of reasoning and argumentation.

Keywords: LOGICAL HYLOMORPHISM, FORM-MATTER DISTINCTION, FORMAL LOGIC, INFORMAL LOGIC, ARGUMENTATION 